高分子化学 (Kobunshi Kagaku), Vol. 30, No. 337, pp. 239-243 (May, 1973!

\title{
[一般諞文 $]$
}

\author{
カルボキシル基，カルボニル基を含むセルロースヘの \\ アクリルアミドのグラフト共重合
}

（受付1972年 7 月20日・掲載決定1973年 1 月 9 日)

\author{
高橋 璋* ・高橋史朗*
}

\begin{abstract}
要 旨 硝酸第二セリウムアンモニウム ( $\mathrm{Ce}$ 塩)を開始郕として, $\mathrm{COOH}$ 基および $\mathrm{C}=\mathrm{O}$ 基 を含むセルロース試料にアクリルアミド $(\mathrm{AM})$ をグラフト共重合させた。グラフト率は $\mathrm{Ce}$ 坆浪度 が $1 \sim 5 \mathrm{mmol} / l$ のとき極大值を示し，その值は試料の $\mathrm{C}=\mathrm{O}$ 基量が增すにつれ高濃度侧に移動し た。初期の重合速度から見かけの活性化エネルギー $5.4 \mathrm{kcal} / \mathrm{mol}$ が得られた。グラフト率, PMA の分子量および見かけの分㞳数は $\mathrm{C}=\mathrm{O}$ 基量が增すにつれ增大し， $\mathrm{COOH}$ 基に影響されない。 グラフトポリマーの赤外吸収スペクトルを測定した。

これらのことから, 重合は $\mathrm{Ce}$ 塩と $\mathrm{C}=\mathrm{O}$ 基のレドックス反応により開始され, 鎖末端への重 合が $\mathrm{OH}$ 基へのそれより優先するものと考えられる。
\end{abstract}

\section{1. 緒言}

セリウムイオンがセルロースに対するグラフト重合の 開始肪になることが見いだされて以来，七ルロースへの ビニルモノマーのグラフト共重合が盛んに行なわれてき た1)

セリウムイオンとセルロースの反応によりポリマーラ ジカルが生成し,

$\mathrm{Ce}^{4+}+\mathrm{RH} \rightleftharpoons$ Complex $\rightarrow \mathrm{Ce}^{3+}+\mathrm{H}^{+}+\mathrm{R}$.

これにビニルモノマーが共存するとグラフト重合が開始 される。

しかしながら，セルロース試料にセリウムイオンを作 用させると，脱水素のほかに $\mathrm{OH}$ 基の酸化，グルコピ ラノシド環の開裂および解重合が起こり, フリーラジカ ルの拠点はかなり複雑化することが予想される。

著者らはこれらのことを追究するため，才キシセルロ 一スをモデル物質として，これに種々のビニルモノマー を重合させ，諸因子の重合に及ぼす影響を検討してい る。

今回はセルロース試料に $\mathrm{NO}_{2}$ ガスを作用させ， $\mathrm{C}_{(6)}$ および $\mathrm{C}_{(2)}, \mathrm{C}_{(3)}$ の $\mathrm{OH}$ 基を $\mathrm{COOH}$ 基および $\mathrm{C}=\mathrm{O}$ 基に酸化した試料，およびこれら試料を $\mathrm{NaClO}_{2}$ ある いは $\mathrm{NaBH}_{4}$ で処理した試料をつくり，これにセリウム イオンを開始剤としてアクリルアミドを重合させ, 開始 用濃度, モノマー滣度, 反応温度および官能基の重合に 及ほす影響を検討した。

\footnotetext{
* 工学院大学工業化学科（東京都新宿区西新宿）
}

2. 実験

\section{1 セルロース試料の調整}

二酸化空素処理セルロース ( $\mathrm{N}$ 試料)

精製リンターを $\mathrm{P}_{2} \mathrm{O}_{5}$ 上の真空デシケーターで乾燥 し,これに $\mathrm{NO}_{2}$ を気化導入し, 室温で所定時間処理し た。

二酸化窒素一亜塩素酸処理セルロース ( $\mathrm{N}-\mathrm{Na}$ 試料)

$\mathrm{N}$ 試料を $1 \mathrm{~mol} / l$ 酢酸を含む $0.2 \mathrm{~mol} / l \mathrm{NaClO}_{2}$ 水溶 液 (浴比50倍) に浸せきし， $20^{\circ} \mathrm{C}$ で72時間処理した ${ }^{2)} 。$

二酸化窒素一水素化ホウ素ナトリウム処理セルロース ( $\mathrm{N}-\mathrm{B}$ 試料)

$\mathrm{N}$ 試料を $1 \mathrm{~mol} / l \mathrm{NaBH}_{4}$ 水溶液（浴比50倍）に浸せ きし，室温で24時間処理した。

\section{2 試 薬}

アクリルアミド (AM) : 市販一級品を30部のベンゼン に加熱溶解し，2回再結晶したものを使用した。

硝酸第二セリウムアンモニウム (Ce 塩)：市販特級品 を用いて $1 \mathrm{~mol} / l \mathrm{HNO}_{3}$ を含む $0.1 \mathrm{~mol} / l \mathrm{Ce}$ 㙁水溶液 をつくり，使用した。

\section{3 重 合}

重合は前報 ${ }^{3)}$ と同様 $\mathrm{N}_{2}$ を充満させた系で行ない，重 合の停止にはヒドロキノン水溶液を使用した。

生成重合体は多量のメタノールを投入し沈殿させた。 つぎにホモポリマーを分離するため， $50 \sim 60^{\circ} \mathrm{C}$ の温湯 で十分抽出した。非抽出分はグラフト重合体とみなし， 全重合率，グラフト率およびグラフト効率を算出した ${ }^{3)}$ 。

\section{4 分子量の測定}

ポリアクリルアミド (PAM) を純水に溶解し，オスト 
Table 1. Cellulosic materials containing carboxyl and carbonyl groups used for graft copolymerization.

\begin{tabular}{|c|c|c|c|c|c|c|c|c|c|}
\hline \multirow{2}{*}{$\begin{array}{c}\text { Sample } \\
\begin{array}{c}\text { Oxidation } \\
\text { time with } \\
\mathrm{NO}_{2}(\mathrm{hr})\end{array}\end{array}$} & \multicolumn{3}{|c|}{$\mathrm{NO}_{2}$} & \multicolumn{3}{|c|}{$\mathrm{NO}_{2}-\mathrm{NaBH}_{4}$} & \multicolumn{3}{|c|}{$\mathrm{NO}_{2}-\mathrm{NaClO}_{2}$} \\
\hline & $\begin{array}{c}\mathrm{COOH} \\
(\mathrm{mmol} / \\
100 \mathrm{~g})\end{array}$ & $\begin{array}{c}\mathrm{CO} \\
(\mathrm{mmol} / \\
100 \mathrm{~g})\end{array}$ & $\begin{array}{c}\mathrm{CO} / \\
\mathrm{COOH}+ \\
\mathrm{CO} \\
\left(\begin{array}{l}0 \\
0\end{array}\right) \\
\end{array}$ & $\begin{array}{c}\mathrm{COOH} \\
(\mathrm{mmol} / \\
100 \mathrm{~g})\end{array}$ & $\begin{array}{c}\mathrm{CO} \\
(\mathrm{mmol} / \\
100 \mathrm{~g})\end{array}$ & $\begin{array}{c}\mathrm{CO} / \\
\mathrm{COOH}+ \\
\mathrm{CO} \\
\left(\begin{array}{l}0 \\
\%\end{array}\right)\end{array}$ & $\begin{array}{c}\mathrm{COOH} \\
(\mathrm{mmol} / \\
100 \mathrm{~g})\end{array}$ & $\begin{array}{c}\mathrm{CO} \\
(\mathrm{mmol} / \\
100 \mathrm{~g})\end{array}$ & $\begin{array}{c}\mathrm{CO} / \\
\mathrm{COOH}+ \\
\mathrm{CO} \\
(\%) \\
\end{array}$ \\
\hline 1 & 0.0 & 3.2 & 10.0 & 1.9 & 0.6 & 24.0 & 2.0 & 4.2 & 67.7 \\
\hline 3 & 5.0 & 9.7 & 66.0 & 5.9 & 1.0 & 14.5 & 8.8 & 5.2 & 37.1 \\
\hline 16 & 11.3 & 7.7 & 40.5 & 8.4 & 5.0 & 37.4 & 17.5 & 5.8 & 24.9 \\
\hline 24 & 25.6 & 14.2 & 35.7 & 18.7 & 5.1 & 21.4 & 27.0 & 3.9 & 12.6 \\
\hline 40 & 57.6 & 15.7 & 21.5 & 47.6 & 7.1 & 13.0 & 61.0 & 6.8 & 10.0 \\
\hline 52 & 124.7 & 21.8 & 14.6 & 99.5 & 6.1 & 5.8 & 91.2 & 8.5 & 8.5 \\
\hline
\end{tabular}

ワルド粘度計を用いて外捜法で還元粘度を測定し，下式 により粘度平均分子量を算出しだ。

$$
[\eta]=4.07 \times 10^{-6} \times M^{1.07}+\left(25^{\circ} \mathrm{C}\right)
$$

見かけの分岐数はセルロース $1 \mathrm{~mol}$ あたりのグラフト 量とホモポリマーの分子量から算出した。

\section{3. 結果と考察}

\section{1 オキシセルロース試料}

グラフト共重合に使用したセルロース試料の $\mathrm{COOH}$ 基, $\mathrm{C}=\mathrm{O}$ 基量をそれぞれ酢酸カルシウム 法 $^{5)}$, 七ミ

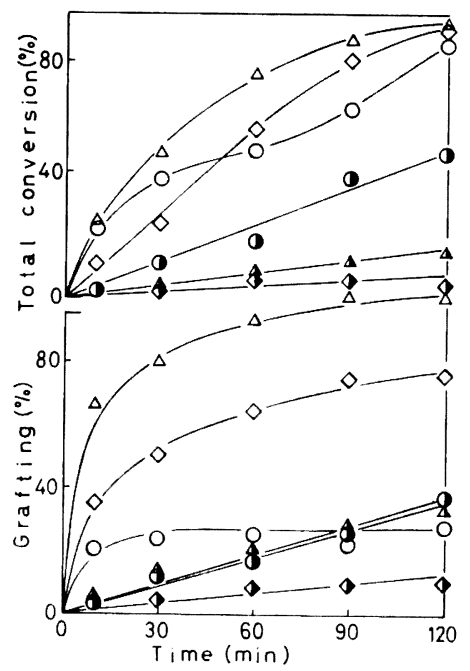

$\mathrm{NO}_{2}$ oxidized cellulose $(\mathrm{COOH} 57.6, \mathrm{CO} 15.7$ $\mathrm{mmol} / 100 \mathrm{~g}$ Cell) Conditions: [M] $0.703 \mathrm{~mol} / \mathrm{l}$, $60^{\circ} \mathrm{C}$

Fig. 1. Effect of grafting time on grafting of acrylamide to $\mathrm{NO}_{2}$ oxidized cellulose (open mark) and cotton linter (half solid mark) at various concentration of ceric ion: $(\bigcirc) 1,(\triangle) 5,(\diamond)$ $15 \mathrm{mmol} / l$.
カルバジド法胡で測定し，その結果を Table 1 に示した。 精製リンターに $\mathrm{NO}_{2}$ ガスを作用させると， $\mathrm{C}_{(6)}$ およ び $\mathrm{C}_{(2)}, \mathrm{C}_{(3)}$ の $\mathrm{OH}$ 基はそれぞれ $\mathrm{COOH}$ 基および $\mathrm{C}=$ $\mathrm{O}$ 基に酸化され7)，処理時間が長くなるにつれ官能基生 成比 $\{\mathrm{C}=\mathrm{O} /(\mathrm{COOH}+\mathrm{C}=\mathrm{O})\}$ は減少した。また, $\mathrm{N}$ 試料に $\mathrm{NaClO}_{2}$ を作用させると, $\mathrm{C}=\mathrm{O}$ 基の一部は $\mathrm{COOH}$ 基に酸化され， $\mathrm{N}$ 試料に $\mathrm{NaBH}_{4}$ を作用させる と， $\mathrm{C}=\mathrm{O}$ 基が $\mathrm{COOH}$ 基に比べて一層還元された。

\section{2 セルロース試料へのアクリルアミドのグラフト 共重合}

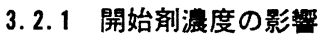

$\mathrm{N}$ 試料 (COOH 基 $57.6, \mathrm{C}=\mathrm{O}$ 基 $15.7 \mathrm{mmol} / 100 \mathrm{~g}$ Cell) にモノマー濃度 $[M] 0.703 \mathrm{~mol} / l$, 所定量の開始剤 を用いて $60^{\circ} \mathrm{C} て ゙$ 所定時間重合させた。

Fig. 1 に示したように, 全重合率は精製リンターが共 存する場合に比べて大きく, 重合時間 2 時間ではモノマ 一の約 $80 \%$ が重合した。また， N試料へのグラフト率が 精製リンターのそれに比べて大きく, 反応の初期に急速 に增大した。このことは, $\mathrm{Ce}$ 塩が試料の $\mathrm{C}=\mathrm{O}$ 基を 攻撃しポリマーラジカルが生成し, 重合が開始するこ とを示唆する。また，重合速度は開始剤濃 度 [I] が 5 $\mathrm{mmol} / l$ のとき最も大きく，それより増すと減少した。

つぎに $\mathrm{N}$ 試料 $(\mathrm{COOH}$ 基 $11.3, \mathrm{C}=\mathrm{O}$ 基 $7.7 \mathrm{mmol} /$ $100 \mathrm{~g} \mathrm{Cell)}$ およびその誘導体である $\mathrm{N}-\mathrm{Na}$ 試料および $\mathrm{N}-\mathrm{B}$ 試料に $[M] 0.703 \mathrm{~mol} / l$, 所定量の Ce 塩を用いて $60^{\circ} \mathrm{C}$ で 2 時間重合させ， [I] の重合に及ぼす影響を検 討した。

Fig. 2 に示したように，グラフト率は $[I]$ が $1 \sim 3$ $\mathrm{mmol} / l$ のとき極大值を示し, そのときの $[I]$ は試料の $\mathrm{C}=\mathrm{O}$ 基量が増すにつれ高濃度側に移動した。

PAM の分子量は [I] が増すにつれ急速に減少し，5 $\mathrm{mmol} / l$ を超えると一定值を示した。一方，見かけの分 岐数はグラフト率一 $[I]$ 曲線と同様に極大值を持つ曲線 で示された。このことから， Ce 塩は開始剤として働く と同時に，分岐鎖長の生長を抑制することが示唆され 


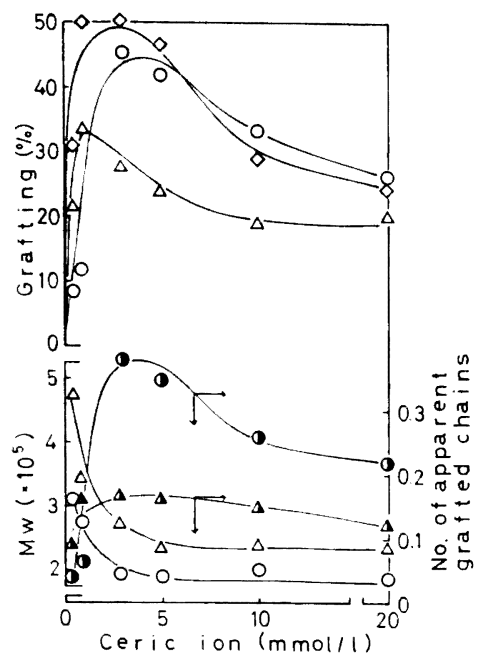

(O): $\mathrm{NO}_{2}$ Cell. (COOH 11.3, $\mathrm{CO} 7.7 \mathrm{mmol} /$ $100 \mathrm{~g}$ Cell)

$(\triangle): \mathrm{NO}_{2}-\mathrm{NaBH}_{4}$ Cell. (COOH 8.4, $\mathrm{CO} 5.0$ $\mathrm{mmol}_{i} 100 \mathrm{~g}$ Cell)

$(\diamond): \quad \mathrm{NO}_{2}-\mathrm{NaClO}_{2}$ Gell. (COOH 17.5, CO

$5.8 \mathrm{mmol} / 100 \mathrm{~g}$ Cell)

Conditions: $[M] 0.703 \mathrm{~mol} / l, 60^{\circ} \mathrm{C}, 2 \mathrm{hr}$

Fig. 2. Effect of concentration of ceric ion on per cent grafting, molecular weight of homopolymer and no. of apparent grafted chains (half solid mark) in grafting of acrylamide to cellulosic materials.

る。なお，見かけの分岐数は枝ポリマーの回収が困難で あり，枝ポリマーとホモポリマーの分子量が等しいとの 報告 ${ }^{8)}$ があるので，ホモポリマーの分子量から算出:し た。

\subsection{2 モノマー濃度の影響}

前記試料に [I] $3 \mathrm{mmol} / l$, 所定量のモ/マーを用い て $60^{\circ} \mathrm{C} て ゙ 2$ 時間重合させ， $[M]$ の重合に及ぼす影響を 検討した。

Fig. 3 に示したように，全重合率はいずれの試料が共 存しても $[M]$ が増すにつれ急速に増大し, $1.5 \mathrm{~mol} / l$ で はモノマーの80〜90\%が重合した。また，グラフト率は $[M]$ の 1 次に比例して増大寸ることがわかる。

\subsection{3 重合温度の影㗄}

$\mathrm{N}$ 試料 (COOH 基 $57.6, \mathrm{C}=\mathrm{O}$ 基 $15.7 \mathrm{mmol} / 100 \mathrm{~g}$ Cell) に $[I] 3 \mathrm{mmol} / l,[M] 0.703 \mathrm{~mol} / l$ と一定に保ち 所定時間重合させ, 反応温度の重合に及ほす影響を検討 した。

Fig. 4 に示したように，初期のグラフト率は反応時間 の1次に比例して, また反応温度が高くなるにつれ增大 し，60，34ㄷでのグラフト率はそれぞれ30，90分で一定

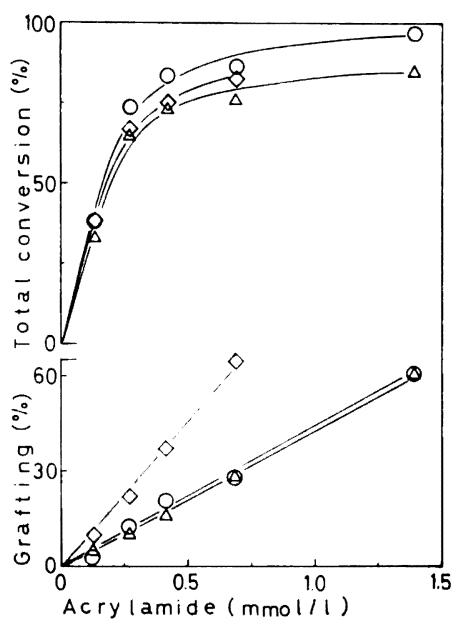

Conditions:

[M] $0.703 \mathrm{~mol} / l, 60^{\circ} \mathrm{C}, 2 \mathrm{hr}$

Fig. 3. Effect of concentration of acrylamide on grafting of acrylamide to cellulosic materials: (O) $\mathrm{NO}_{2},(\diamond) \mathrm{NO}_{2}-\mathrm{BaBH}_{4},(\triangle) \mathrm{NO}_{2}-\mathrm{Na}$ $\mathrm{ClO}_{2}$.

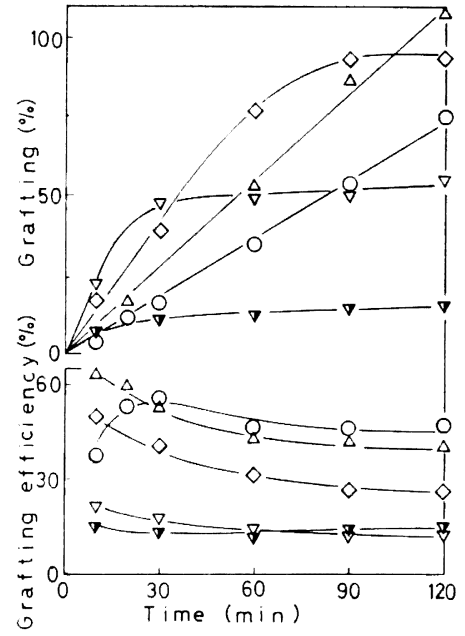

$\mathrm{NO}_{2}$ oxidized cellulose $(\mathrm{COOH} 57.6, \mathrm{CO} 15.7$ $\mathrm{mmol} / 100 \mathrm{~g}$ Cell)

Fig. 4. Effect of grafting time and temperature on per cent grafting and grafting efficiency in grafting of acrylamide to $\mathrm{NO}_{2}$ oxidized cellulose (open mark) and cotton linter (half solid mark) at: $(\bigcirc) 14,(\triangle) 24,(\diamond) 34,(\nabla) 60^{\circ} \mathrm{C}$.

となる。

比較のため精製リンターへのグラフト率を示したが， $\mathrm{N}$ 試料のそれに比べてかなり小さい。一方，グラフト効 


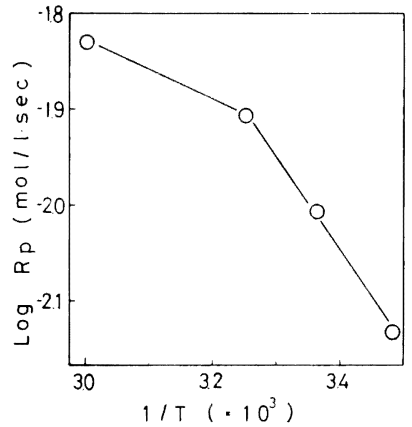

Fig. 5. Apparent rate of graft copolymerization as a function of reciprocal of absolute temperature.

率は反応時間が長く，高温での反応において減少した。

Fig. 5 に初期の重合速度の対数と絶対温度の逆数の関 係を示した。これより，14 35 $\mathrm{C}$ の温度範囲で直 線 関 係が得られ，その勾配から重合の見かけの活性化エネル ギー $5.4 \mathrm{kcal} / \mathrm{mol}$ が得られた。この值は過酸化物触媒に よるビニル重合の $20 \mathrm{kcal} / \mathrm{mol}$ に比べてかなり低く，さ らに Ce 塩が還元性の有機基とコンプレックスをつくり やすいことから ${ }^{1)}$, 重合は $\mathrm{Ce}$ 塩と $\mathrm{C}=\mathrm{O}$ 基の相互作 用，すなわちレドックス的な触媒作用により開始するも のと考えられる。

\section{2.4 官能基の影響}

Table 1 に示した官能基量の異なる $\mathrm{N}$ 試料およびその 誘導体に $[I] 3 \mathrm{mmol} / l,[M] 0.703 \mathrm{~mol} / l$ と一定に保ち, $24^{\circ} \mathrm{C}$ で 1.5 時間重合させ，官能基の重合に及ぼす影響を 検討した。な抢，セルロース試料を $\mathrm{pH} 3.6,0.05 \mathrm{~mol} / l$ 過ヨウ素酸ナトリウム水溶液で処理し, $\mathrm{C}_{(2)}, \mathrm{C}_{(3)}$ のOH

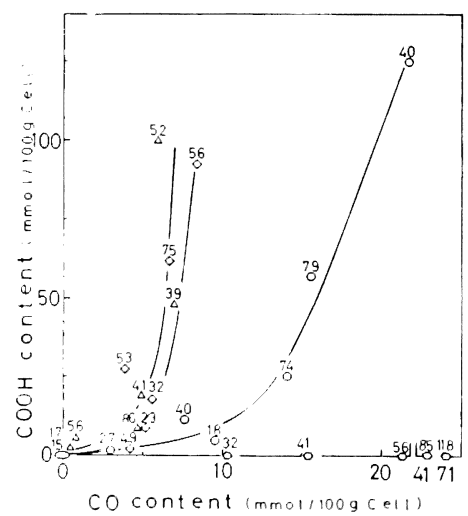

Conditions: $[M] 0.703 \mathrm{~mol} / l, 24^{\circ} \mathrm{C}, 1.5 \mathrm{hr}$

Fig. 6. Effect of functional groups in grafting of acrylamide to cellulosic materials: (O) $\mathrm{NO}_{2}$, $(\triangle) \mathrm{NO}_{2}-\mathrm{NaBH}_{4},(\diamond) \mathrm{NO}_{2}-\mathrm{NaClO}_{2}$, $\mathrm{H}$, (O) cotton linter.
基を $\mathrm{C}=\mathrm{O}$ 基に酸化した試料（ $\mathrm{H}$ 試料 $)^{9)}$ をつくり， $\mathrm{N}$ 資料の場合と同じ条件でAMを重合させた結果も示し $た^{10)}$ 。

Fig. 6 に示したように，H試料を除くと，いずれの試 料も $\mathrm{COOH}$ 基と $\mathrm{C}=\mathrm{O}$ 基を含むことから, $\mathrm{COOH}$ 基， $\mathrm{C}=\mathrm{O}$ 基を両軸にとり，グラフト率をプロットし た点上に表示した。これより， $\mathrm{H}$ 試料へのグラフト率は $\mathrm{C}=\mathrm{O}$ 基量が增すにつれ增大することがわかる。 $\mathrm{N}$ 試料 およびその誘導体へのグラフト率もまた $\mathrm{C}=\mathrm{O}$ 基量が 増すにつれ増大するが，多量の $\mathrm{COOH}$ 基が存在すると 減少した。これは, $\mathrm{COOH}$ 基と Ce 塩により塩が生成 し， Ce 塩の活性が低下したことによるものと考えられ る。

$\mathrm{N}$ - $\mathrm{Na}$ 試料へのグラフト率は $\mathrm{N}$ 試料の $\mathrm{C}=\mathrm{O}$ 基の一 部が $\mathrm{COOH}$ 基に酸化されたにもかかわらずかなり大き い。このことは， N試料を $\mathrm{NaClO}_{2}$ で処理するときセ ルロース鎖が切断され，その鎖末端にグラフトされるこ とを示唆する。また， $\mathrm{N} 一 \mathrm{~B}$ 試料へのグラフト率は $\mathrm{N} お$ よび $\mathrm{N}-\mathrm{Na}$ 試料へのグラフト率より小さく, 精製リン ターへのそれに比べて大きいことから，OH 基へのグラ フト重合は起こりにくいものと考えられる。

つぎに，官能基のグラフト鎖長に及ぼす影響を検討す るため，セルロース試料への重合により生成したホモポ リマーの分子量を測定し，見かけの分岐数を算出した。

Fig. 7 に示したように， $\mathrm{G}=\mathrm{O}$ 基がおよう $10 \mathrm{mmol} /$ $100 \mathrm{~g}$ Cell より少ない試料への重合における PAM の分 子量は，精製リンターへの重合に打けるそれと大差ない が， $\mathrm{C}=\mathrm{O}$ 基量が増すと増大した。

一方，見かけの分岐数は官能基量が増し，七ルロース

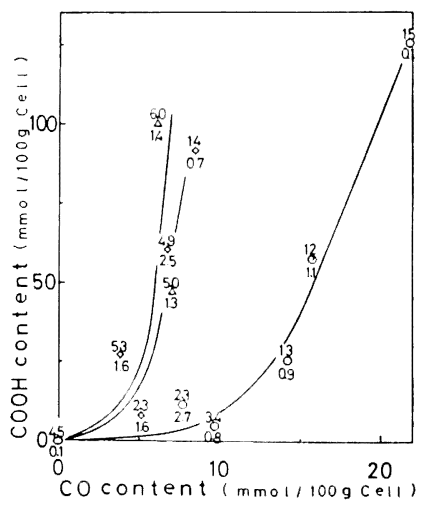

Fig. 7. Effect of functional groups on molecular weight of homopolymer (upper no., $\times 10^{4}$ ) and no. of apparent grafted chains (lower no.) in grafting of acrylamide to cellulosic materials: (○) $\mathrm{NO}_{2},(\triangle) \mathrm{NO}_{2}-\mathrm{NaBH}_{4}, \quad(\diamond) \mathrm{NO}_{2}-$ $\mathrm{NaClO}_{2}$, (O) cotton linter.

高分子化学, Vol. 30, No. 337 (May, 1973) 
カルボキシル基, カルボニル基を含むセルロースヘのアクリルアミドのグラフト共重合

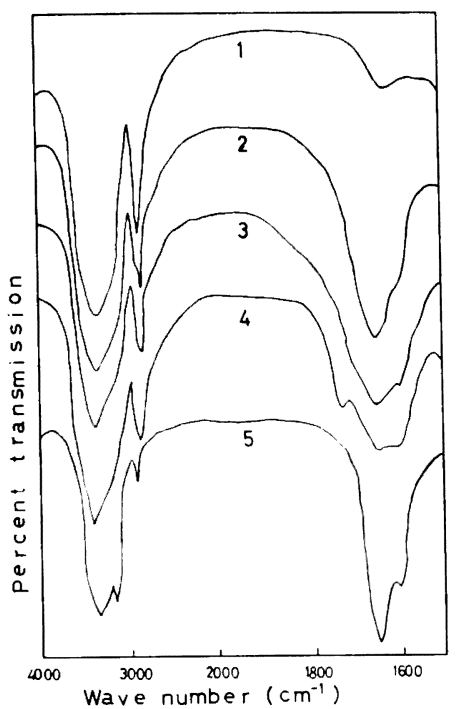

2: Backbone polymer, COOH 5.0, CO $9.7 \mathrm{mmol} /$ $100 \mathrm{~g}$, Grafting $17.5 \%$

3: Backbone polymer, $\mathrm{COOH} 11.3$, CO 7.7 $\mathrm{mmol} / 100 \mathrm{~g}$, Grafting $60.0 \%$ 4: Backbone polymer, $\mathrm{COOH} 124.7, \mathrm{CO} 21.8$ $\mathrm{mmol} / 100 \mathrm{~g}$, Grafting $4.0 \%$

Fig. 8. IR spectra of cotton linter (1), graft- $-(2,3,4)$ and homo-polymers (5).

鎖の切断の程度の大きい試料において大きく, N-Na および $\mathrm{N}$ 一B 試料への分岐数が試料のそれに比べて大き い。このことは，鎖末端への重合が $\mathrm{OH}$ 基へのそれに 優先することを示唆し，岩倉らの Ce 塩の存在下，七ル ロースモデル化合物に AM を重合させて得られた結 果 ${ }^{11)}$ と一致する。

\subsection{5 赤外吸収スペクトル}

日本分光制製 IR-G 型分光光度計を用いて， $N$ 試料 と AM の共重合により生成したポリマーの赤外吸収 ス ペクトルを測定した。

Fig. 8 に示したように，グラフトポリマーおよびホ モポリマーのスペクトルは，いずれも $1665 \mathrm{~cm}^{-1}, 1610$ $\mathrm{cm}^{-1}$ に一級アミドの吸収が存在し, 二級アミドの吸収 (1550 $\mathrm{cm}^{-1}$ 付近）が見られない。このことから AM は
二重結合が重合し，水素移動重合は起こらないことを示 し，ラジカル重合に打ける重合様式と一致する た，グラフト共重合体の $1750 \mathrm{~cm}^{-1}$ のレ $\mathrm{C}=0$ 吸収バン ド (4) は $\mathrm{N}$ 試料の $\mathrm{C}=\mathrm{O}$ 基が赤外吸収を持たないことか $ら^{13)}, \mathrm{COOH}$ 基に起因するものと考えられる。

$2900 \mathrm{~cm}^{-1}$ 付近の $\nu_{\mathrm{CH}}$ 吸光度はセルロース含量が增す につれ増大することから，七ルロースに起因することが わかる。図は省略したが，一級アミドによる 1665 , $1610 \mathrm{~cm}^{-1}$ の吸光度を $2900 \mathrm{~cm}^{-1}$ の $\nu_{\mathrm{CH}}$ 吸光度で割った 吸光度比はグラフト量が増すにつれ増大することから， これら吸光度比を用いてグラフト量を測定することがで きる。

付記 本稿は昭和47年 5 月纎維学会春期研究発表会 （東京）で発表したものである。

\section{文献}

1) G. Mino, S. Kaizerman: J. Polym. Sci., 31, 243 (1958)

2) H. A. Rutherford, F. W. Minor: J. Research Natl. Bur. Standards, 29, 131 (1942)

3) 高橋璋, 高橋史朗：工化, 74, 2541 (1971)

4) B. Baysal, G. Adler, D. Ballantine, A. Glines: J. Polym. Sci., B1, 5, 257 (1963)

5) G. F. Davidson, T. P. Nevell: J. Textile Inst., 39, T102 (1948)

6) 渡辺貞良，桑名謙一：紙 パ技協誌， 10,524 (1956)

7) T. P. Nevell: J. Textile Inst., 42, T91 (1951)

8) Cr. Simionescu, S. Oprea: Rev. Roum. Chim., 1968, 13 (6), 793

9) G. F. Davidson: J. Textile Inst., 31, T81 (1940); 32, T108 (1941)

10) 高橋璋, 高橋史朗：日化24年会講演予 稿集, p. 2267 (1971)

11) Y. Iwakura, T. Kurosaki, Y. Imai: J. Polym. Sci., A3, 1185 (1965)

12) K. Yokota, Y. Sakai, Y. Ishii: J. Polym. Sci., B3, 839 (1965)

13) H. Speding: J. Chem. Soc., 1960, 3147; H. G. Higgins, A. W. McKenzic: Australian J. Appl. Sci., 9, 167 (1958) 